\title{
Evaluation of Roof Bolting Requirements Based on In-Mine Roof Bolter Drilling
}

(Contract No. DE-FC26-01NT41056)

Project Duration: Dec. 18, 2000 - Dec. 17, 2003

\section{Quarterly Technical Progress Report}

Report Period

October 1, 2002 - December 31, 2002

Syd S. Peng (Principal Investigator)

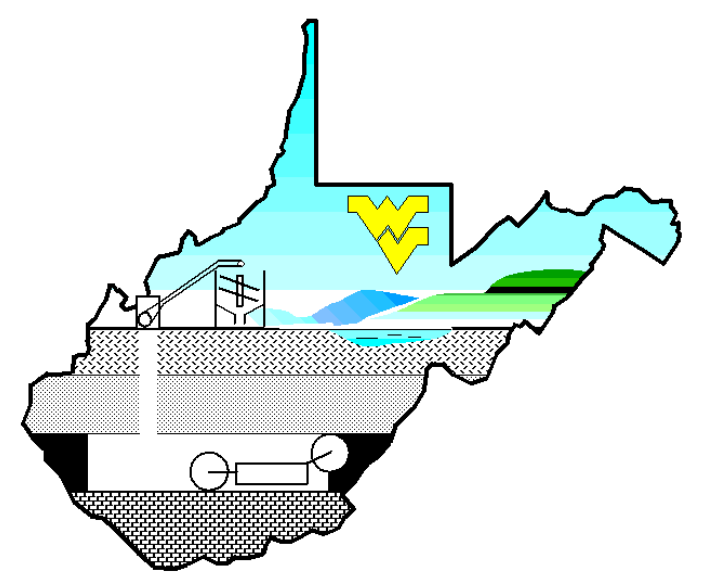

Department of Mining Engineering

West Virginia University

Morgantown, WV 26506-6070

Tel: 304-293-7680 ext. 3301

E-mail: sspeng@mail.wvu.edu

January 15, 2003 


\title{
DISCLAIMER
}

This report was prepared as an account of work sponsored by an agency of the United States Government. Neither the United States Government nor any agency thereof, nor any of their employees, makes any warranty, express or implied, or assumes any legal liability or responsibility for the accuracy, completeness, or usefulness of any information, apparatus, product, or process disclosed, or represents that its use would not infringe privately owned rights. Reference herein to any specific commercial product, process, or service by trade name, trademark, manufacturer, or otherwise does not necessarily constitute or imply its endorsement, recommendation, or favoring by the United States Government or any agency thereof. The views and opinions of authors expressed herein do not necessarily state or reflect those of the United States Government or any agency thereof.

\begin{abstract}
Additional field tests have been performed. It is found that the drilling power can be used as a supplementary method for detecting voids/fractures and rock interfaces.
\end{abstract}




\section{TABLE OF CONTENTS}

Disclaimer
Abstract
Research Objectives
Experimental
Results and Discussion
1. Characterizing the Rock Strata
2. Exploring the Roof Bolting Mechanisms
3. Development of On-Board Data Visualization and Database Program

Conclusions

Reference 


\section{RESEARCH OBJECTIVES}

Roof bolting is the most popular method for underground openings in the mining industry, especially in the bedded deposits such as coal, potash, salt etc. In fact, all U.S. underground coal mine entries are roof-bolted as required by law.

However, roof falls still occur frequently in the roof bolted entries. The two possible reasons are: the lack of knowledge of and technology to detect the roof geological conditions in advance of mining, and lack of roof bolting design criteria for modern roof bolting systems.

This research is to develop a method for predicting the roof geology and stability condition in real time during roof bolting operation. Based on such information, roof bolting design criteria for modern roof bolting systems will be developed for implementation in real time.

For the prediction of roof geology and stability condition in real time, a microprocessor will be used and a program (ROOFSTAB) developed to monitor the drilling parameters. These parameters include thrust, penetration rate, rotation torque, rotation rate, drill position, and vacuum condition. At the same time, rock cores will be obtained a borehole drilled immediate next to bolt hole for the determination of the mechanical properties and structure of the rock strata within the bolting horizon. A relationship or relationships will be established between these drilling parameters and the mechanical and structural data of the roof strata. A roof bolter control system will be developed to monitor these drill parameters. For the development of ROOFSTAB drilling parameters will be obtained from four different coal seams in four mine sites. With this information, a computer program will be developed for use in conjunction with the roof bolter for realtime prediction of strata mechanical properties and structures in roof strata within the bolting horizon.

For the development of roof bolting design criteria, numerical simulations will be performed to investigate the mechanisms of modern roof bolting systems including both the tension and non-tensioned (or fully grouted) bolts. Parameters to be studied are: bolt size/strength, bolt length, bolt spacing, grout annulus and length, and roof geology (massive strata, fractured, and laminated or thinly-bedded). The results of these experiments will be analyzed to develop a roof bolting criterion or criteria program (ROOFBOLT) that will be combined with the ROOFSTAB for use in conjunction with roof bolt installation.

The following main tasks are to be performed for achieving the proposed research objectives:

A. Development of Operator Control Technology for Monitoring Roof Bolter Drill Operations Parameters.

B. Laboratory and Underground Testing.

C. Drill Parameters Data Analysis and Correlation with Roof Stability Conditions Software Development for Mapping of Roof Geological Conditions

D. Laboratory Tests to Investigate the Mechanisms of Roof Bolting Using Simulated Materials

E. Development of Roof Bolting Design Criteria for Implementation in Primary Roof Bolting Cycle 


\section{EXPERIMENTAL}

Two sets of field tests have been performed in a Marrowbone coal mine located in Southern West Virginia. The immediate mine roof at this site was weak shale. However, intrusion of strong sandstone pots was observed at various locations. The tests were performed at and near one of the sandstone intrusion for the drilling holes to penetrate from the weak shale into the hard sandstone at different depths.

\section{RESULTS AND DISCUSSION}

The objective of this research project is to develop the methodology for evaluating the geology and stability condition of the roof strata of underground openings in realtime during roof bolting operation. Based on such information, bolting requirements for modern roof bolting systems will be developed for implementation in real time. The following main items of works performed in this reporting period are listed:

\section{Characterizing the Rock Strata}

Analysis on the drilling power has been performed. This method shows some promising sign to be used as a supplementary method for detecting voids and fractures in the bolting horizon.

\section{Exploring the Roof Bolting Mechanisms}

In studying the mechanisms involved in roof bolting, three-dimensional finite element models for simulating the tensioned bolt have been developed and refined. Twodimensional finite element models for simulating the fully grouted resin bolts have also been developed and refined. The effects of sliding and separation of bedding planes have been considered in these models. Based on the numerical modeling results, the design criteria for tensioned and fully grouted resin bolts are being developed. The yielding zone developed over the entry can be used to determine the bolt length, the magnitude of plastic strain can be used to judge the roof local stability, and the stress distribution around the entry and bolt load are also used to check roof stability.

\section{Development of On-Board Data Visualization and Database Pro- gram}

The development of a computer program to display the original and derived drilling parameters, the identified rock types and geological structures in the bolting horizon in 2-D and 3-D is continuing in this quarter. 


\section{Progress on Planned Tasks}

\begin{tabular}{rl|c}
\hline \hline \multicolumn{1}{c|}{ Tasks Planned in the Proposal } & Progress \\
\hline A. $\quad \begin{array}{c}\text { Development of Operator Control Technology for Monitoring } \\
\text { Roof Bolter Drill Operation Parameters }\end{array}$ & As detailed in item No. 1 \\
\hline B. $\quad$ Laboratory and Underground Testing & As detailed in item No. 1 \\
\hline C. $\quad \begin{array}{c}\text { Drill Parameter Data Analysis and Correlation with Roof Stability } \\
\text { Conditions }\end{array}$ & As detailed in item No. 1 \\
\hline D. $\quad \begin{array}{c}\text { Software Development for Mapping of Roof Geological Condi- } \\
\text { tions }\end{array}$ & As detailed in item No. 3 \\
\hline E. $\quad \begin{array}{c}\text { Computer Modeling to Investigate the Mechanisms of Roof Bolt- } \\
\text { ing }\end{array}$ & As detailed in item No. 2 \\
\hline F. $\quad \begin{array}{c}\text { Development of Roof Bolting Design Requirements for Imple- } \\
\text { mentation in the Primary Roof Bolting Cycle }\end{array}$ & As detailed in item No. 2 \\
\hline \hline
\end{tabular}

\section{CONCLUSIONS}

Additional field tests have been performed. It is found that the drilling power can be used as a supplementary method for detecting voids/fractures and rock interfaces.

\section{REFERENCE}

Luo, Y. S.S. Peng, B. Mirabile, G. Finfinger and G. Wilson, 2002, "Estimating Rock Strengths Using Drilling Parameters During Roof Bolting Operations - Progresss Report," Proc. 21st Int'l Conference on Ground Control in Mining, Ed. S.S. Peng, C. Mark and A.W. Khair, pp. 288-293.

Yassien, A., Y.Q. Zhang, J.S. Han and S.S. Peng, 2002, "Comparison of Some Aspects of Bolting Mechanisms Between Fully-Grouted Resin and Tensioned Bolts in Underground Mine Entries," Proc. 21st Int'l Conference on Ground Control in Mining, Ed. S.S. Peng, C. Mark and A.W. Khair, pp. 114-125.

Zhang, Y.Q. and S.S. Peng, 2002, "Design Considerations for Tensioned Bolts," Proc. 21st Int'l Conference on Ground Control in Mining, Ed. S.S. Peng, C. Mark and A.W. Khair, pp. 131-140. 